\title{
Evaluation of enzyme immunoassay (Chlamydiazyme) for detecting Chlamydia trachomatis in genital tract specimens
}

\author{
D TAYLOR-ROBINSON, BRENDA J THOMAS, MARY F OSBORN \\ From the Division of Sexually Transmitted Diseases, Medical Research Council Clinical Research Centre, \\ Harrow, Middlesex and the Jefferiss Research Wing, Praed Street Clinic, St Mary's Hospital, London
}

SUMmARY An enzyme immunoassay (Chlamydiazyme) for detecting Chlamydia trachomatis was evaluated on genital specimens from 96 men and 272 women attending a clinic for sexually transmitted diseases (STD clinic). Compared with a direct immunofluorescence test for chlamydial elementary bodies, the enzyme immunoassay had a sensitivity of $58 \%$ on specimens from men, a specificity of $99 \%$, a positive predictive value of $93 \%$, and a negative predictive value of $88 \%$; the assay had a sensitivity of $67 \%$ on specimens from women, a specificity of $89 \%$, a positive predictive value of $63 \%$ and a negative predictive value of $90 \%$. Immunofluorescence provided the most stringent test for the performance of the enzyme immunoassay as values were improved a little when a cell culture procedure was used for comparison. Further evidence for the lack of sensitivity was the detection of elementary bodies, sometimes in large numbers, in the enzyme immunoassay buffer of 13 of 19 specimens that had given a negative enzyme immunoassay result and the finding in com parative titrations of four laboratory strains that the enzyme immunoassay was at least 100 -fold less able to detect chlamydiae than either immunofluorescence or the cell culture procedure. Lack of specificity may be associated with the finding that the enzyme immunoassay antibody reacted with strains of Acinetobacter calcoaceticus, Escherichia coli, Gardnerella vaginalis, Neisseria gonorrhoeae and group B streptococci. The enzyme immunoassay was not considered to be sufficiently sensitive, specific, or reproducible for routine use.

We have already examined the value of a fluorescein labelled monoclonal antibody (MicroTrak; Syva) to detect Chlamydia trachomatis elementary bodies directly in genital smears. ${ }^{1}$ Compared with isolation of the organisms in cell culture, the fluorescence technique was found to be both sensitive and specific. These findings were consistent with those of other workers ${ }^{2}$ and were substantiated later in a study of adult conjunctivitis. ${ }^{3}$ The fluorescence technique has been used for research and diagnostic purposes subsequently, and two of us (BJT and MFO) have examined more than 10000 genital and ocular specimens in this way over the past two years. ${ }^{4}$ The procedure is, however, labour intensive and fatiguing and, therefore, techniques that are independent of microscopical observation must be considered. Enzyme immunoassays have this advantage and have been used by several groups of workers. ${ }^{5-17}$ We report here our experience in testing both clinical specimens

Accepted for publication 11 August 1986 and laboratory strains of $C$ trachomatis using the Chlamydiazyme (Abbott) enzyme linked immunosorbent assay (ELISA), comparing the results with those obtained by the fluorescence method and, in some instances, by isolation in cell culture.

\section{Material and methods}

PATIENTS

Men seen at the Praed Street Clinic (St Mary's Hospital), with symptoms and signs of urethritis or epididymitis, and those seeking reassurance, were studied. Specimens were collected mainly from those with untreated non-gonococcal urethritis (NGU), which was diagnosed if there were $\geqslant 10$ polymorphonuclear leucocytes per high power microscope field $(\times 800)$ in a Gram stained smear of urethral discharge, if diplococci were not seen, and if subsequent culture for gonococci was negative. Women studied were contacts of men with NGU or those who came within a clinical category considered 
to require testing for chlamydiae, such as cervicitis, pelvic inflammatory disease, or lower abdominal pain.

\section{PROCEDURE}

Material from the male urethra was obtained by inserting an ENT swab (MW 142; Medical Wire and Equipment $\mathrm{Co}$, Corsham, Wiltshire) $3-5 \mathrm{~cm}$ into the urethra and then rolling the swab on a MicroTrak slide. A second specimen was taken with the swab provided as part of the Chlamydiazyme kit and this swab replaced in its container.

Cervical specimens were obtained by inserting a cotton tipped swab into the endocervical canal and rotating it to remove epithelial cells. It was rolled on a MicroTrak slide and in one series the same swab was expressed in $1.0 \mathrm{ml}$ of chlamydial sucrosephosphate transport medium (2SP with $10 \%$ inactivated fetal calf serum), which was snap frozen and stored in liquid nitrogen. A second specimen was taken with the Chlamydiazyme swab. In one series endourethral and cervical swabs were taken in this order on two consecutive days and in the reverse order on the next two consecutive days.

\section{CHLAMYDIAZYME TEST}

This enzyme immunoassay (EIA) was performed according to the manufacturer's instructions. Specimens kept at $4^{\circ} \mathrm{C}$ were processed within five days of collection. One $\mathrm{ml}$ of specimen dilution buffer was added to each tube containing a swab. The tubes were kept at room temperature for 10 minutes and then agitated on a vortex mixer for three cycles of $15 \mathrm{sec}-$ onds, after which the swabs were expressed and discarded. The sample extract $(0.2 \mathrm{ml})$ and controls (positive and negative specimens supplied in the kit) were placed in the wells of plastic plates and one treated polystyrene bead added to each well and the plate incubated at $37^{\circ} \mathrm{C}$ for one hour. Then each bead was washed four times with $5 \mathrm{ml}$ of distilled water for the first series of clinical specimens, by using a hand held multichannel washer (Pentawash) and for the second series, by automatic washing with the Pentawash device (the Proquantum system). The addition of rabbit antichlamydial antibody (one hour at $37^{\circ} \mathrm{C}$ ) was followed by the same washing procedure and then by horseradish peroxidase conjugated antibody to rabbit IgG (one hour at $37^{\circ} \mathrm{C}$ ) and further washing. The beads were transferred to the tubes provided, and $0.3 \mathrm{ml}$ of freshly prepared peroxidase substrate (ortho-phenylenediamine-hydrogen peroxide) was added to each tube. The tubes were kept at room temperature for 30 minutes in the dark, the reaction stopped with $1 \mathrm{~N}$ sulphuric acid, and absorbance determined at $492 \mathrm{~nm}$. A result was considered to be positive if the optical density exceeded the mean of the three negative controls plus $0 \cdot 1$. The results of the enzyme immunoassay were recorded without knowledge of the results of the other tests.

\section{MICROTRAK IMMUNOFLUORESCENCE TEST}

The fixing of genital smears and their examination after treatment with the "MicroTrak $C$ trachomatis direct fluorescence antibody reagent" was undertaken as described previously. ${ }^{1}$ The numbers of elementary bodies in smears and in Chlamydiazyme buffer fluid were recorded using the following scale: $\pm=1-10$; $+=11-100 ;++=101-1000 ;+++=>1000$.

ISOLATION AND TITRATION OF CHLAMYDIAE The clinical specimens in 2SP medium in liquid nitrogen were thawed rapidly. Chlamydiae were isolated in McCoy cells treated with cycloheximide, as described previously, ${ }^{18} 0.5 \mathrm{ml}$ of a specimen being inoculated into each of two cell monolayer cultures, which, after incubation at $37^{\circ} \mathrm{C}$ for 48 hours, were stained with Giemsa and examined for inclusions. The same procedure was used to assess the number of infectious elementary bodies in stock cultures of known chlamydial serovars. These were diluted serially in 10-fold steps, and $0.5 \mathrm{ml}$ of the suspension at each dilution was inoculated into two cell cultures; titres are expressed as inclusion forming units (ifu) per ml.

\section{TRACHOMATIS STRAINS}

In addition to clinical specimens, strains of $C$ trachomatis that had been passed in McCoy cell cultures were used to test the sensitivity of the enzyme immunoassay. These comprised strain $\mathrm{SA}_{2}$ (f) (LGV2 serovar) and strain UW31 (K serovar), both of which had had multiple passes in culture, and strain Boyd (infant ocular isolate) and strain 59828 (cervical isolate), both of which had been passed once after primary isolation in cell culture.

\section{BACTERIAL STRAINS}

To examine the specificity of the enzyme immunoassay tests were undertaken with suspensions of various bacteria (table 1), some of which are found in the urogenital tract. Bacterial colonies from primary cultures were picked and subcultured to agar media. Colonies from these pure cultures were removed with a cotton tipped swab and suspensions prepared in phosphate buffered saline (PBS; pH 7-2). A volume of $0.1 \mathrm{ml}$ was added to the Chlamydiazyme dilution buffer, which was processed as described previously. The number of organisms in the suspension was determined by making serial 10 -fold dilutions in PBS and inoculating $0.1 \mathrm{ml}$ on to the appropriate agar medium. The media were incubated at $37^{\circ} \mathrm{C}$ and colonies counted when there was no further development. Titres are expressed as colony forming units (cfu) per ml. 
Table 1 Reactivity of Chlamydiazyme with micro-organisms other than $C$ trachomatis

\begin{tabular}{|c|c|c|c|}
\hline \multirow[b]{2}{*}{ Micro-organism } & \multicolumn{2}{|c|}{ No of strains } & \multirow[b]{2}{*}{ No of organisms in test } \\
\hline & Tested & Reactive in enzyme immunoassay & \\
\hline $\begin{array}{l}\text { Acinetobacter calcoaceticus } \\
\text { Candida albicans } \\
\text { Escherichia coli } \\
\text { Gardnerella vaginalis } \\
\text { Neisseria gonorrhoeae } \\
\text { Staphylococcus aureus } \\
\text { Streptococcus (group A) } \\
\text { (group B) }\end{array}$ & $\begin{array}{l}1 \\
3 \\
1 \\
7 \\
2 \\
1 \\
1 \\
2\end{array}$ & $\begin{array}{l}1 \\
0 \\
1 \\
3 \\
2 \\
0 \\
0 \\
1\end{array}$ & $\begin{array}{l}10^{5} \\
? \\
10^{7} \\
10^{6}-10^{7} \\
10^{4}, 2 \times 10^{7} \\
10^{7} \\
10^{7} \\
10^{7}\end{array}$ \\
\hline
\end{tabular}

\section{Results}

\section{COMPARISON OF ENZYMEIMMUNOASSAY WITH} IMMUNOFLUORESCENCE FOR TESTING CLINICAL SPECIMENS

In the first series of tests on 152 specimens the Pentawash system was used and the results compared with those obtained by immunofluorescence on specimens taken second (table 2). The sensitivity of the enzyme immunoassay was relatively low (70\%), as was the positive predictive value $(63 \%)$.

In a second series of tests on 216 specimens the Proquantum system was used and the results compared with those obtained by immunofluorescence on duplicate specimens. They were not influenced by taking the specimens for the enzyme immunoassay either first or second. Overall, the results were similar to those obtained in the first series, the sensitivity of the enzyme immunoassay being a little less (62\%) and the positive predictive value a little greater $(72 \%)$ (table 3). Table 4 gives the results of the two series combined on a total of 368 specimens: the results are presented for men and women separately. The enzyme immunoassay was insensitive for detecting chlamydiae in specimens from both men and women. The assay was specific for chlamydiae in specimens from men but less so in specimens from women.

Table 2 Performance of Chlamydiazyme (Pentawash system) using MicroTrak immunofluorescence as standard test

\begin{tabular}{|c|c|c|c|}
\hline \multicolumn{4}{|c|}{ No of specimens $=152 ; 104$ women and 48 men } \\
\hline Sensitivity & $\frac{\text { EIA }+, \mathbf{I F}+}{\text { IF }+}$ & $\frac{19}{27}$ & $70 \%$ \\
\hline Specificity & $\frac{E I A-, I F-}{I F-}$ & $\frac{114}{125}$ & $91 \%$ \\
\hline Positive predictive value & $\frac{\text { EIA }+, \text { IF + }}{\text { EIA }+}$ & $\frac{19}{30}$ & $63 \%$ \\
\hline Negative predictive value & $\frac{\text { EIA - IF - }}{\text { EIA - }}$ & $\frac{114}{122}$ & $93 \%$ \\
\hline
\end{tabular}

USE OF CELL CULTURES IN ADDITION TO

\section{IMMUNOFLUORESCENCE FOR EVALUATING}

\section{ENZYME IMMUNOASSAY}

In the second series of tests mentioned above specimens from 142 patients were examined not only by the enzyme immunoassay and immunofluorescence but also by the cell culture procedure. As expected, the results of comparing the former two tests on this number of specimens were similar to those obtained previously on the larger number of specimens (table 3). Thus the enzyme immunoassay, compared with immunofluorescence, had a sensitivity of $60 \%$, a specificity of $97.5 \%$, a positive predictive value of $82 \%$ and a negative predictive value of $90 \%$. Fifteen cell cultures inoculated with specimens from women became bacterially contaminated so that culture results were available only on 127 specimens. In tests on these the enzyme immunoassay, compared with culture, had a sensitivity of $67 \%$, a specificity and positive predictive value of $100 \%$, and a negative predictive value of $94 \%$. By contrast, the immunofluorescence test on the same patients, when compared to culture, had a sensitivity of $95 \%$, a specificity of $97 \%$, a positive predictive value of $87 \%$ and a negative predictive value of $99 \%$. These results indicated that comparison with immunofluorescence provided the most stringent test for the performance of the enzyme immunoassay.

Table 3 Performance of Chlamydiazyme (Proquantum system) using MicroTrak immunofluorescence as standard test

No of specimens $=216 ; 168$ women and 48 men

\begin{tabular}{|c|c|c|c|}
\hline Sensitivity & $\frac{\mathbf{E I A}+, \mathbf{I F}+}{\mathrm{IF}+}$ & $\frac{36}{58}$ & $62 \%$ \\
\hline Specificity & $\frac{E I A-, I F-}{I F-}$ & $\frac{144}{158}$ & $91 \%$ \\
\hline Positive predictive value & $\frac{\text { EIA }+, \text { IF }+}{\text { EIA }+}$ & $\frac{36}{50}$ & $72 \%$ \\
\hline Negative predictive value & $\frac{\mathbf{E I A}-, \mathbf{I F}-}{\mathbf{E I A}-}$ & $\frac{144}{166}$ & $87 \%$ \\
\hline
\end{tabular}


Table 4 Performance of Chlamydiazyme in tests on 368 clinical specimens using MicroTrak immunofluorescence as standard test

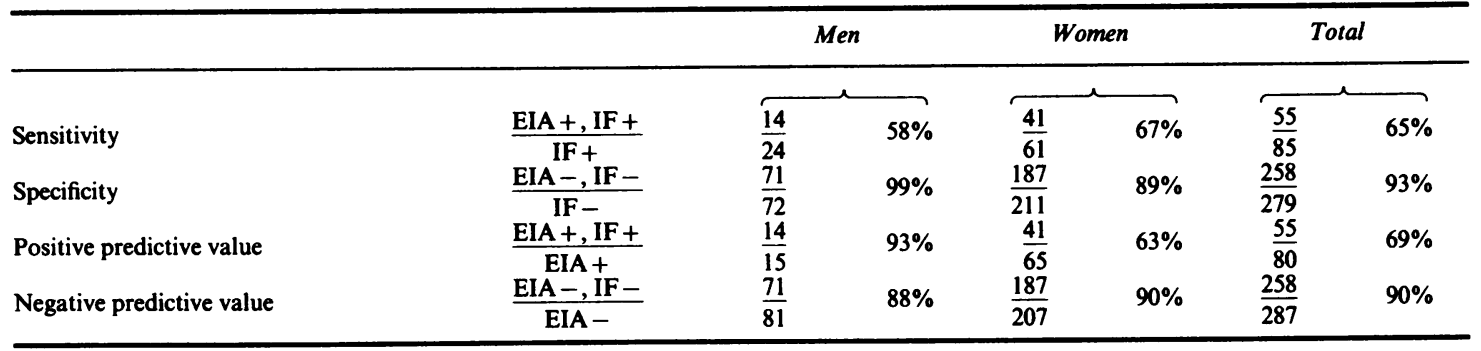

Table 5 Presence or absence of elementary bodies in Chlamydiazyme buffer of clinical specimens providing discordant enzyme immunoassay and immunofluorescence results

\begin{tabular}{|c|c|c|c|c|c|c|c|c|}
\hline \multirow[b]{2}{*}{ No of specimens } & \multirow{2}{*}{$\begin{array}{l}\text { Chlamydiazyme } \\
\text { result }\end{array}$} & \multirow{2}{*}{$\begin{array}{l}\text { Original Micro Trak } \\
\text { result }\end{array}$} & \multicolumn{6}{|c|}{ No of samples with indicated no of elementary bodies in buffer } \\
\hline & & & Inadequate & - & \pm & + & ++ & +++ \\
\hline $\begin{array}{r}16 \\
6 \\
14\end{array}$ & $\overline{\bar{t}}$ & $\begin{array}{l} \pm \\
-\end{array}$ & $\begin{array}{l}3 \\
0 \\
0\end{array}$ & $\begin{array}{r}5 \\
1 \\
14\end{array}$ & $\begin{array}{l}3 \\
4 \\
0\end{array}$ & $\begin{array}{l}2 \\
0 \\
0\end{array}$ & $\begin{array}{l}0 \\
0 \\
0\end{array}$ & $\begin{array}{l}3 \\
1 \\
0\end{array}$ \\
\hline
\end{tabular}

Scale: $\pm=1-10 ;+=11-100 ;+t=101-1000 ;+++=>1000$.

\section{IMMUNOFLUORESCENCE TESTS ON SAMPLES IN CHLAMYDIAZYME BUFFER}

Thirty six specimens in the second series (table 3 ), for which the results of the enzyme immunoassay and immunofluorescence were discordant, were reassessed by taking the original enzyme immunoassay buffer solutions in which the specimens had been placed and testing them by immunofluorescence. As shown in table 5 , of 22 specimens negative originally by the enzyme immunoassay but positive by immunofluorescence, 19 were adequate for testing by immunofluorescence and 13 were found to have elementary bodies in the buffer solution; in four instances the numbers were more than 1000 . On the other hand, of 14 specimens that were positive originally by the enzyme immunoassay but negative by immunofluorescence, none was found to have elementary bodies in the buffer solution. These observations vindicated the original results recorded by immunofluorescence and indicated that the enzyme immunoassay lacked sensitivity.

\section{TITRATION OF LABORATORY STRAINS OF} CHLAMYDIAE

Two strains of $C$ trachomatis that had had multiple passes in cell culture and two strains that were in their second pass only were subjected to serial 10 -fold dilution; each dilution was examined by enzyme immunoassay and immunofluorescence and tested also in cell culture. Table 6 shows the results. In each case the highest dilutions at which elementary bodies were seen by immunofluorescence and inclusions were seen in cell culture were similar, whereas the highest dilution at which the enzyme immunoassay was positive was at least 100 -fold less, indicating the inferior sensitivity of enzyme immunoassay.

\section{REPRODUCIBILITY OF ENZYME IMMUNOASSAY}

Sixteen specimens were tested by enzyme immunoassay on three occasions within nine hours. Seven specimens were positive every time, although only four of the patients from whom these specimens were derived had been positive when tested originally by

Table 6 Comparative sensitivity of Chlamydiazyme and MicroTrak immunofluorescence for detecting laboratory strains of C trachomatis

\begin{tabular}{|c|c|c|c|c|}
\hline \multirow[b]{2}{*}{ Strain } & \multicolumn{2}{|c|}{ Highest dilution positive in specimen buffer by: } & \multirow{2}{*}{$\begin{array}{l}\text { Titre in cell } \\
\text { culture } \\
\text { (ifu/ml) }\end{array}$} & \multirow{2}{*}{$\begin{array}{l}\text { Fold difference in sensitivity } \\
\text { between enzyme immunoassay } \\
\text { and other tests }\end{array}$} \\
\hline & Enzyme immunoassay & Immunofluorescence & & \\
\hline $\begin{array}{l}\mathrm{SA}_{2}(\mathrm{f}) \text { a) } \\
\text { b) } \\
\text { UW } 31(\mathrm{~K}) \\
\text { Baby Boyd P2 (Eye) } \\
59828 \text { P2 (Cx) }\end{array}$ & $\begin{array}{l}10^{-4} \\
10^{-5} \\
10^{-5} \\
10^{-3} \\
10^{-3}\end{array}$ & $\begin{array}{l}\left.10^{-7} \text { ( } 2 \text { elementary bodies }\right) \\
10^{-7}(2 \text { elementary bodies }) \\
10^{-7}(3 \text { elementary bodies }) \\
\left.10^{-5} \text { ( } 3 \text { elementary bodies }\right) \\
\left.10^{-5} \text { (4 elementary bodies }\right)\end{array}$ & $\begin{array}{l}1 \times 10^{7} \\
1 \times 10^{7} \\
9 \times 10^{6} \\
5 \times 10^{4} \\
\text { NT }\end{array}$ & $\begin{array}{l}10^{3} \\
10^{2} \\
10^{2} \\
10^{2} \\
10^{2}\end{array}$ \\
\hline
\end{tabular}

*MicroTrak staining of $10 \mu \mathrm{l}$ of Chlamydiazyme specimen buffer taken after Chlamydiazyme testing. 
immunofluorescence. One specimen was negative on each occasion by enzyme immunoassay and was also negative by immunofluorescence. The remaining eight specimens produced no consistent pattern, some being positive on first testing by the enzyme immunoassay and negative subsequently, others exhibiting the reverse pattern.

TESTS ON MICRO-ORGANISMS OTHER THAN CHLAMYDIAE BY USING ENZYME IMMUNOASSAY Table 1 shows that strains of Acinetobacter calcoaceticus, Escherichia coli, Gardnerella vaginalis, Neisseria gonorrhoeae and group B streptococci reacted positively when tested by enzyme immunoassay. The numbers of some of these micro-organisms that reacted are in keeping with numbers that might occur in clinical specimens.

\section{Discussion}

It is difficult to analyse the results of other workers and assess why some of them ${ }^{71011} 13^{15-17}$ have concluded that the enzyme immunoassay that we used was satisfactory for testing clinical specimens. Several aspects are, however, pertinent. First, spurious values may be derived if the test used for comparison is lacking in sensitivity and specificity-for example, the enzyme immunoassay may appear falsely sensitive if an insensitive cell culture procedure is used for comparison; there is no doubt that the ability to detect chlamydiae in cell culture varies from one laboratory to another. Furthermore, the elimination of specimens that destroy cell cultures may falsify a comparative assessment. The value of using a comparative procedure such as immunofluorescence, which is independent of cell sensitivity and the problems of detecting inclusions in cells, is obvious. It must be admitted, however, that the value of the immunofluorescence procedure depends on the ability of the observer, and a spurious comparison with the enzyme immunoassay may be made as easily as by using cell culture. It is clear that valid comparisons will be made only when tests, of whatever sort, are undertaken in ideal conditions in the most capable hands. Our use of cell culture as a comparative procedure did not produce results much different from those obtained by using immunofluorescence as the comparison, although immunofluorescence provided the more stringent test for the performance of the enzyme immunoassay. Overall, comparative tests of either sort on clinical samples indicated quite clearly that the enzyme immunoassay is insufficiently sensitive for detecting chlamydiae in specimens from both men and women and insufficiently specific for chlamydiae in specimens from women.

The need for the assay is greater in women but the positive predictive value of $63 \%$ means that of every 10 positive results obtained, only about six will be correct. This is unacceptable even in our high prevalence group, and in a low prevalence group could apparently double the positivity rate. The negative predictive value of $90 \%$ in women means that of every 10 negative results one should be positive. Again, this could assume greater importance in a low prevalence group. Our experience extends over a year with kits from different batches, so any suggestion that only a single kit is at fault is unfounded; so too is the suggestion that inexperience with the enzyme immunoassay procedure initially may account for poor results as these did not improve in later tests. Furthermore, evidence for insensitivity of the enzyme immunoassay based on testing clinical samples is supported by our other observations - namely, the finding of chlamydial elementary bodies, sometimes in large numbers, in the enzyme immunoassay buffer for specimens which provided a negative enzyme immunoassay result and the finding in comparative titrations that the enzyme immunoassay was at least 100-fold less able to detect chlamydiae than either immunofluorescence or the cell culture procedure. In clinical practice the enzyme immunoassay does not seem to have this degree of insensitivity, probably because some of the specimens contain inclusion containing cells that disintegrate during processing to produce a positive result. Nevertheless, quantitative tests undertaken by diluting suspensions of laboratory strains are easy to perform, and we suggest that they should be done by both manufacturers and laboratory workers before large numbers of tests are undertaken on clinical samples. It is premature to expend effort on widespread clinical testing unless, in such a titration procedure, the sensitivity of the enzyme immunoassay begins to match that of competently undertaken immunofluorescence or cell culture procedures, or both. It seems unlikely, however, that any enzyme immunoassay system could be made sufficiently sensitive to detect one chlamydial elementary body, even those that are amplified in some way. ${ }^{1114}$

In our tests lack of reproducibility and specificity have also been disappointing. Lack of specificity may be due to cross reactivity with micro-organisms other than chlamydiae and has been mentioned previously in the case of Acinetobacter sp. ${ }^{19}$ Our results confirm this and indicate that other bacteria found in the genital tract may create a problem and account for poor specificity in enzyme immunoassay tests on specimens from women. The possibility that cross reactivity occurs because this enzyme immunoassay is based on a polyclonal rather than a monoclonal antibody should be considered.

Finally, the availability of animal models of $C$ tra- 
chomatis infection ${ }^{20}$ provides an excellent opportunity for comparing chlamydial detection procedures. Models based on small animals, in particular, ${ }^{21}$ enable specimens from numerous animals to be collected easily, repeatedly, and over a prolonged period. For those who have such models available, it seems sensible to gauge the sensitivity and specificity of a particular technique in this way. Inadequacy indicated in such tests implies that it would not be profitable to undertake the more difficult task of testing human clinical specimens, a procedure which inevitably thrusts a burden on clinic staff and facilities.

We thank all the staff of the Praed Street clinic for their invaluable help in the collection of specimens and Ms Jenny Stirling and Ms Yvonne Boustouller for the various freshly isolated bacteria used in specificity testing.

\section{References}

1 Thomas BJ, Evans RT, Hawkins DA, Taylor-Robinson D. Sensitivity of detecting Chlamydia trachomatis elementary bodies in smears by use of a fluorescein-labelled monoclonal antibody: comparison with conventional chlamydial isolation. $J$ Clin Pathol 1984;37:812-6.

2 Tam MR, Stamm WE, Handsfield HH, et al. Cultureindependent diagnosis of Chlamydia trachomatis using monoclonal antibodies. $N$ Engl $J$ Med 1984;310:1146-50.

3 Hawkins DA, Wilson RS, Thomas BJ, Evans RT. Rapid, reliable diagnosis of chlamydial ophthalmia by means of monoclonal antibodies. Br J Ophthalmol 1985;69:640-4.

4 Thomas BJ, Osborn MF, Munday PE, et al. Detection of Chlamydia trachomatis in smears by a fluorescent monoclonal antibody: observations during two years based on ten thousand patients. Genitourin Med (In press).

5 Terho P, Matikainen MT. Detection of Chlamydia trachomatis antigen by radioimmunoassay. J Immunoassay 1981;2:239-62.

6 Caldwell HD, Schachter J. Immunoassay for detecting Chlamydia trachomatis major outer membrane protein. J Clin Microbiol 1983;18:539-45.

7 Jones MF, Smith TF, Houglum AJ, Herrmann JE. Detection of Chlamydia trachomatis in genital specimens by Chlamydiazyme test. J Clin Microbiol 1984;20:465-7.

8 Matikainen MT, Lehtonen OP. Relation between avidity and specificity of monoclonal anti-chlamydial antibodies in cultural supernatants and ascitic fluids determined by enzyme immunoassay. J Immunol Methods 1984;72:341-7.

9 Stokes GV, Kahn MW. Enzyme-linked immunosorbent assay for the detection of chlamydial antigens from human specimens. Microbios 1984;40:15-23.

10 Amortegui AJ, Meyer MP. Enzyme immunoassay for detection of Chlamydia trachomatis from the cervix. Obstet Gynecol 1985;65:523-6.

11 Caul EO, Paul ID. Monoclonal antibody based elisa for detecting Chlamydia trachomatis. Lancet 1985;i:279.

12 Hambling MH, Kurtz JB. Preliminary evaluation of an enzyme immunoassay test for the detection of Chlamydia trachomatis. Lancet 1985; ;:53.

13 Mumtaz G, Mellars BJ, Ridgway GL, Oriel JD. Enzyme immunoassay for detection of Chlamydia trachomatis antigen in urethral and endocervical swabs. J Clin Pathol 1985;38:740-2.

14 Pugh SF, Slack RCB, Caul EO, Paul ID, Appleton PN, Gatley S. Enzyme amplified immunoassay: a novel technique applied to direct detection of Chlamydia trachomatis in clinical specimens. J Clin Pathol 1985;38:1139-41.

15 Chernesky MA, Mahony JB, Castriciano S, et al. Detection of Chlamydia trachomatis antigens by enzyme immunoassay and immunofluorescence in genital specimens from symptomatic and asymptomatic men and women. $J$ Infect Dis 1986;154:141-8.

16 Howard LV, Coleman PF, England BJ, Herrman JE. Evaluation of Chlamydiazyme for the detection of genital infection caused by Chlamydia trachomatis. J Clin Microbiol 1986;23:329-32.

17 Mohanty KC, O'Neill JJ, Hambling MH. Comparison of enzyme immunoassays and cell culture for detecting Chlamydia trachomatis. Genitourin Med 1986;62:175-6.

18 Thomas BJ, Evans RT, Hutchinson GR, Taylor-Robinson D. Early detection of chlamydial inclusions combining the use of cycloheximide-treated McCoy cells and immunofluorescence staining. J Clin Microbiol 1977;6:285-92.

19 Saikku P, Puolakkainen M, Leinonen M. Nurminen M, Nissinen A. Cross-reactivity between Chlamydiazyme and Acinetobacter strains. New Engl J Med 1986;314:922-3.

20 Taylor-Robinson D. The role of animal models in chlamydial research. In: Oriel D, Ridgway G, Schachter J, TaylorRobinson D, Ward M, eds. Chlamydia infections. Cambridge: Cambridge University Press, 1986:355-66.

21 Tuffrey M, Falder P, Gale J, Taylor-Robinson D. Salpingitis in mice induced by human strains of Chlamydia trachomatis. $\mathrm{Br} J$ Exp Pathol 1986;67:605-16.

Requests for reprints to: Dr D Taylor-Robinson, Division of Sexually Transmitted Diseases, MRC Clinical Research Centre, Watford Road, Harrow, Middlesex HA1 3UJ, England. 